\title{
Speech Communication Related to the Process of Traditional Therapeutic Efforts among the Baduy People in Lebak Regency, Indonesia
}

\author{
HERIYANTO \\ EKANING KRISNAWATI \\ ELIS SURYANI N. S. \\ EVA TUCKYTA SARI SUJATNA \\ KASNO PAMUNGKAS \\ Universitas Padjadjaran, Indonesia
}

\begin{abstract}
Speech communication employs various and complex expressive ways ranging from linguistic to extralinguistic features, and it studies the interaction between the speaker and listener, including interpersonal interaction like the one between a patient and his or her traditional healer. This article discusses some of the issues concerning the language used in the traditional healing process which uses Baduy mantra among the community. Therefore, this study is interdisciplinary in nature and the overall approach is qualitative. Methodology-wise, this research is conducted using discourse analysis and an ethnography of communication. There are two aims from this study, which are: 1) to point out the linguistic and extralinguistic features utilised in the communication component related to activities contributing to the healing process; 2 ) to describe the meaning of the mantra used in the process of therapeutic practices; 3 ) to reveal the patterns of the Baduy medicinal mantra perceived from an ethnography of communication point of view. The results of the research indicate that the mimetic and expressive functions of mantra reflect the role of traditional therapeutic efforts as well as interpersonal relations among the members of the community. The extralinguistic elements are employed to arouse suggestion in order to support the effort of a treatment.
\end{abstract}

Keywords: Baduy, communication, linguistic, extralinguistic, mantra.

\section{INTRODUCTION}

Speech communication employs various and complex expressive ways ranging from linguistic to extralinguistic features, and it studies the interaction between the speaker and listener, including interpersonal interaction like the one between a patient and his or her traditional healer. How people generate shared meaning through the use of verbal and nonverbal symbols plays a very important role in the process of traditional healing as to give support to the patient to gain strength to recover from his or her illness. Traditional healing is meant to build or maintain health, which should be understood to cover biological, psychological, social, and spiritual aspects (Basit, 2017). For the traditional healer, it is a must to develop confidence and effectiveness in the course of the therapeutic process to give a positive impact on the patient. Among the Baduy community, who live in Lebak Regency, Indonesia, the medicinal mantra is often used to cure people from certain illnesses. Mantra, a kind of poetic form or can be regarded as one of the oldest forms of literature, is still maintained up to present time, and is still used in traditional healing by villagers. The study on medicinal mantra found in the Baduy area as a part of Lebak Regency, Indonesia is still important to be carried out in order to support the enhancement of health care in the mentioned region. The other name of Baduy people is Urang Kanekes, the name they usually call themselves. This community can be divided into two major groups, namely Inner Baduy (Baduy Dalam) and Outer Baduy (Baduy 
Luar). They are aware of how important the environment is for their healthy life, so they always maintain their surroundings, and they have a unique way to keep their life in harmony with nature. They are also very interested in traditional herbal medicine because a lot of them still live in remote areas which are relatively far from the location of the hospital, where modern medicine and healthcare access are located. Besides, financially it is regarded as a cheaper treatment. In addition, up till now many people still believe that it is safer and more natural to heal using traditional herbal medicine. The other factor that encourages the use of herbal medicine, which mostly is based on the folk knowledge, is that they can get the herbs easily because they usually grow them around their house (Ekadjati, 2014; Suriyani, 2017b, 2018). A similar study conducted by Napoli (2008) describes how plants, rituals, and spells are used in Sicily, Italy as an alternative treatment for helminthiasis. Her research concludes that conventional medicine has given satisfactory results.

Herbal medicines, although now often modified, produced, marketed and served in a modern way, are still used or consumed by a lot of Baduy people and, because many of them are still of the opinion that for a long time, herbal medicines have proved their effectiveness in curing some illnesses. Besides, as has been previously mentioned, a lot of people believe that they are safer than chemical drugs; and because they are made purely from various plants, they are believed to have better compatibility with the human body. In the course of the traditional treatment process in many Baduy villages, very often while giving herbal medicines to the patients, the traditional healers practice uttering medicinal mantra as has been studied by several researchers (Sucipto \& Limbeng, 2007; Suryani, 2017a, 2017b, 2018). However, the study on Baduy medicinal mantra from the linguistic and extralinguistic point of views is considered by many as still rare.

\section{Communication, Language and Medicinal Mantra}

Communication is the key factor in the success of various activities, including any effort in therapeutic fields. When it comes to the communication between a speaker/sender to hearer/receiver, it employs complex ways ranging from linguistic or verbal features to extralinguistic or nonverbal features. In the course of a traditional treatment process, an exchange of thought, information and emotion between a patient and the traditional medical practitioner or healer is of great importance because no modern equipment is used. Any decision or act taken by the healer is merely on the basis of their communication and what the healer sees and thinks. Often, certain barriers come up when there is no sufficient information received by the healer or in the contrary too many complex messages received at the same time, for instance when a patient tells a lot of what he feels or suffers. In such a case, a communication which primarily refers to spoken verbal communication can also employ extralinguistic or non-verbal elements, even interpersonal interaction factors to support the conveyance of meaning or intention. As a type of face-to-face communication, the interaction between a patient and the healer may become clearer because of the body language and voice tone that usually play a significant role (Ferguson \& Candib, 2002; Riley, 2008; Vaishnav, 2016). In Baduy traditional treatment, however, it is not only the dialogue between a patient and the healer that plays an important role but also the monologue in the form uttering mantra by the healer, combined with the traditional herbal medicine that has been used for a long time, from generation to generation. A similar process has been identified by Napoli (2008) in which spells 
and prayers play an important role. The knowledge of herbal medicine has existed since decades or even hundreds of years ago and used by the ancestors in their daily life.

A mantra which is widely used in everyday life of the Baduy people consists of mystic words or expressions that are believed to possess a special spiritual power. These words or expressions are repeatedly uttered when someone is using it to reach his goal. It is often in the form of a poem or a hymn that concentrates the power of language in order to get spiritual/supernatural power or magic (Sucipto \& Limbeng, 2007; Suryani 2017a, 2017b, 2018).

The language in a mantra is like in a poem but the words chosen are those that are believed to have magical power. The characteristics of a mantra is as follows:

a. The words are carefully chosen and classified according to the type of mantra.

b. $\quad$ The words are used or uttered repeatedly to give a special effect (to the patient).

c. Many of the words chosen are archaic (old words) to raise an ancient atmosphere.

d. The mantra is spoken or uttered in such a way to produce mystical surroundings.

\section{Cultural Aspects of Baduy People}

The knowledge possessed by an ethnic group cannot be separated from society and culture where it exists and grows up for decades or even hundreds of years. Therefore, the study related to such knowledge is intertwined with the studies on culture and society. Baduy people have their own knowledge which indicates the best way of life of that society. Besides, it also reflects the social norms existing among the people and becomes the tool to unify the whole society because it comprises general ethics to be obeyed by all members of the society. In other words, in general, it guides how people behave or do something correctly or in a proper manner. When a member of the society falls ill, for instance, what should be done, how, by whom etc. that is expected can help the patient recover his or her condition can be regarded as an example of the knowledge of that society. However, what is good or considered to be appropriate in one society at a certain time may become inappropriate in a different society. Uttering mantra while giving a traditional herbal medicine to a patient among Baduy people is considered appropriate, but it may be regarded as inappropriate in modern big cities, although various herbal medicines are still in use. This indicates that by knowing the mindset or the way of thinking of a community, mutual understanding can be reached, and it is very important for a nation like Indonesia which consists of many ethnic groups who have different mindsets and also have different customs (Saini, 2005; Suryani, 2017a).

In connection with traditional Baduy herbal medicine as a part of their knowledge, it is important to point out that up till now a great deal of the people still make use of various plants as traditional medicine, and they have done it since hundreds of years ago. They consume or use it as an alternative to modern medicine or as a kind of supplement. In line with The World Health Organisation statement which describes traditional herbal medicine as comprising therapeutic practices that have been in existence for a long time, it can be said that the Baduy traditional medicine belongs to those therapeutic efforts based on the system of traditional medicine as part of their culture (Packer, Choon, \& Halliwell, 2004; Suryani, 2017a, 2017b).

In Baduy therapeutic practices, the traditional preparations consist of selected certain leaves, seeds, flowers and roots of the herbs found around their surroundings. Besides, they also use water, minerals such as salt, palm sugar etc. These practices are derived from the 
excellent tradition of their ancestors' civilization and belief as to the forms of cultural heritage. Sometimes the herbal remedy is presented in the form of a very popular drink (called bandrek) and ginger candy (called permen jahe) that consist of ginger, palm sugar, a little pepper, a little salt etc., which is good for influenza, for example (Packer, Choon, \& Halliwell, 2004; Sucipto \& Limbeng 2007; Arora, 2010). In the past, such a drink was only traditionally home-made and often sold around the village. This drink which comprises nutritionally and medicinally enhanced ingredients, in the sense of better quality and healthier in the process of production, is still very popular not only among villagers in Lebak Regency but also in big cities all around West Java.

Culture is the whole system of ideas, actions and creation of a community or society that become their specific belongings or possessions as a result of the process of learning and usually these possessions become the characteristics of a certain group of people living in one particular area. These people are usually considered as a unit because of their common interests, background and also speak the same language and have the same ancestors. In other words, culture is related to a community-specific idea about what is true, good, beautiful, and efficient. To be cultural, those ideas about truth, goodness, beauty, and efficiency must be socially inherited and customary, and they may also gain through a long process of learning, besides those ideas actually can be applied in different aspects of life appropriately, in the sense that those qualities remain the same in different situations, not contradictory. Among Baduy people, for instance, uttering medicinal mantra while giving traditional herbal medicine is considered good, correct and proper. Therefore, to be accepted as a member of a certain community an individual must understand the norms existing among the whole community, so that he can behave appropriately (Hunn in Harrison \& Huntington, 2000; Sucipto \& Limbeng, 2007; Riley, 2008; Iskandar \& Budiawati, 2017).

This article discusses some of the issues concerning the language used in the traditional healing process which uses Baduy mantra among the community. There are two aims of this interdisciplinary study. Firstly, it aims to point out the linguistic and extralinguistic features utilised in the communication component related to activities contributing to the healing process. Secondly, this study hopes to describe the meaning of the mantra used in the process of therapeutic practices. Last but not least, this study aims to reveal the patterns of the Baduy medicinal mantra perceived from the ethnography of communication point of view.

\section{METHODOLOGY}

This research employs a descriptive qualitative method with an ethnography of communication and ethnolinguistic approaches. Data collection is conducted by using several techniques, namely observation, interviews, and document study, where the document study is used as the complement of observation and interviews. The main objects in the research are interactions between patients and traditional healers and the medicinal mantra that exist among the Baduy people and they are analysed from the linguistic and extralinguistic point of views supported by Baduy cultural background.

\section{RESULTS AND DISCUSSION}

Unlike the development of herbal medicine in big cities, in rural areas where local people still hold tight their tradition and belief, and they are obliged to live a simple life, herbal medicine generally remains the same as it was a long time ago. Often, among Baduy people, the effort of curing disease not only involves the traditional herbal medicine but also the medicinal 
mantra, words or utterances which are believed to possess a special spiritual power to cure the patient; and this unique way of conducting therapeutic practices can only be carried out by certain people or traditional healers with special knowledge and ability.

Among the Baduy people, the mantra is closely related to their belief and knowledge, and it has various structures, uses, functions, and meanings, which are complementary to each other. From the point of view of its development, hundreds of years ago in their efforts to solve many kinds of problems in their daily life, the people used their traditional knowledge system which was still very limited. Because of this, and also their simple way of life with only limited ability, too, they often tried to find a solution through many kinds of supernatural ways based on their strong belief in God, and one of them is in the form of medicinal mantra. In general, the Baduy supernatural practice in the form of uttering mantra cannot be separated from their belief in the power caused by the invisible and incredible force. The aim of using mantra in the traditional therapeutic practice is to strengthen the effectiveness of the herbal medicine consumed by the patient. It is clear here that the local wisdom of the Baduy people can be observed from how they try to solve a problem as an illness where they not only make an effort physically but also mentally, not only outer health of the patient but also the inner health. However, in the Baduy belief, the performing of the healing practice by uttering mantra cannot be conducted anytime. It must be carried out at a certain occasion which is usually considered appropriate in accordance to their belief, and not all people can carry out this kind of healing practice because it needs special skills and knowledge in the world of Baduy herbal medicine, massage and belief as well. Therefore, traditional healers have a significant role in the community, especially those living in villages that relatively far from health facilities (Lingpa, Rinpoche, \& Mahapandita, 2006; Sucipto \& Limbeng, 2007; Suryani, 2017a, 2017b, 2018).

In such a healing process interpersonal communication is crucial, and it is true that communication is not just about talking and writing, we express things to others by gestures, facial expressions, smiles and even tears, besides, of course with words and utterances. In interpersonal interactions like the one between a patient and the traditional healer, all those elements play an important role in order to build a conducive atmosphere for gaining a kind of hypnotic condition, so that the patient can be cured more effectively. Among Baduy people where traditional therapeutic efforts are still widely in use, besides communication in the forms of verbal and nonverbal, or linguistic and extralinguistic elements of interaction, the mantra in combination with herbal medicine is also often applied by the healer to cure the patient, as can be scrutinised in the following dialogue.

\section{Data 1}

Conversation excerpt from a traditional healer

The patient (a boy) : Assalamualaikum (Peace be upon you).

The healer (an old man): Waalaikumsalam (Peace be upon you, too). Kunaon eta leungeun? (What's wrong with your arm?)

The patient (a boy) : Labuh, Ki, tina tangkal jambu (I fell down, Ki, from a guava tree). The healer (an old man): Oh, lalaki mah kudu kuat. Sok diuk kadieu, Jang,

ku Aki urang ubaran, diikhtiaran, sugan Allah marengkeun.

(Oh, a boy must be strong. Sit over here, son, 
I'll try to cure you, we just try, may God help us).

The patient (a boy) : Aamiiin (Amen).

This interaction is in the form of interpersonal communication and took place in the simple guest's room of the traditional healer's house which was made of wood and bamboo, and the healer had no special room for curing his patients. There were a few wooden chairs and a kind of simple wooden bed beside an old small wooden cupboard where he kept virgin coconut oil and dried herbal medicines. There was no special equipment for curing his patient, except small utensils made of stone, clay, wood, bamboo even coconut shell for making herbal medicines or putting substances for the process of healing. Beside his simple house, there was a small garden where he grew various herbal plants that could be used anytime he needed to help his patients. There were no modern equipment nor electricity, too, because the community were accustomed to living a very simple life.

The short conversation above illustrates an interpersonal communication between a patient and the traditional healer. As the guest and the patient at the same time, the boy spoke Assalamualaikum first, and the healer replied Waalaikumsalam. These greetings originally come from Arabic expressions whose meanings, more or less, are 'Peace be upon you' and 'Peace be upon you, too'. These utterances are also regarded as prayers, with the sense that Allah will give His blessings to them. Some of the Baduy people are Muslims and some others, especially those who belong to the Inner Baduy community, are the followers of Sunda Wiwitan but they live in a very harmonious way. The opening remarks of the interaction mentioned above are used for asking for help and protection from Allah the Almighty God so that they can live in peace. And in order to show his empathy, the healer then asked Kunaon eta leungeun? 'What's wrong with your arm?', and the boy answered Labuh, Ki, tina tangkal jambu 'I fell down, Ki, from a guava tree'. The boy addressed the healer with the word Ki from Aki which is used to greet an old man. The original meaning is grandpa, but it is used widely towards old men to show respect.

In his attempt to give spirit to the patient, the healer said Oh, lalaki mah kudu kuat 'Oh, a boy must be strong', so that the patient had enthusiasm, eagerness, energy and bravery to fight the pain and to be recovered since the healing process of a broken arm is usually painful. The next sentence in the above communication is an imperative Sok diuk kadieu, Jang 'Sit down over here, son' which indicates that the old man had more power than the boy so that he could order the boy to sit down near him. The word Jang 'son' is used to call a boy and shows that the speaker is older and usually has higher social status than the hearer. The following expression is ku Aki urang ubaran ' $I$ 'll try to cure you', which was uttered in a confident manner, illustrates that the healer had sufficient knowledge in the traditional therapeutics so that he was willing to cure his patient.

However, the next expression diikhtiaran, sugan Allah marengkeun 'we just try, may God help us', shows that the healer realised there was greater power above him. He just made an attempt but the decision or the result depended on the Almighty God. This closing part of the communication reveals that the community is religious, which is also shown by the boy's response Aamiin 'Amen' or 'May God grant our wish'.

In the course of the healing process, besides herbal medicines, the healer also made use of medicinal mantra which is, linguistically, in the form of a monologue although implicitly it is spoken to the Almighty God, Allah. It is like a prayer but fully arranged based on the 
traditional Sundanese culture; and like in the conversation previously discussed, it is entered with an awareness that only Allah who has the real power as indicates by the expression Bismillah 'in the name of Allah, the Almighty God'. Muslims usually speak Bismillah when starting to do anything good in order to get His blessings. It also indicates that although the healer had sufficient knowledge in traditional treatment, he was aware that anything depended on Allah, the Almighty God.

The body of the mantra is, of course, not arbitrarily arranged. The structure of the mantra for a broken arm is clearly composed in such a way like the structure of an arm where the outer part is the skin so that the first line of the mantra's body or the second line of the whole mantra is about the skin, which says Kulit tepung kulit 'the skin meets the skin'. Then, under the skin there is the vein as expressed in the construction Urat tepung urat the vein meets the vein', and also the tissue as in Lamad tepung lamad 'the tissue meets the tissue'. The inner part of the arm is the bone, as expressed in the line which says Tulang tepung tulang 'the bone meets the bone'. This the core of the mantra's body like the bone in the inner part of an arm, as follows.

\section{Data 2}

Mantra and its translation

Jampe Potong Tulang (Mantra for the Broken Arm)

Bismillah (in the name of Allah, the Almighty God)

Kulit tepung kulit (the skin meets the skin)

Urat tepung urat (the vein meets the vein)

Lamad tepung lamad (the tissue meets the tissue)

Tulang tepung tulang (the bone meets the bone)

Pet rapet ku kersaning Allah (united becoming one because of Allah)

Such a Sundanese poetic mantra is uttered while the traditional healer or masseur is giving herbal medicine or herbal essence mixed with virgin coconut oil for massaging. One of the substances contained in such oil is scientifically called zingiberene, a substance extracted from ginger which has a long history as stimulating and warming, and it is believed to be able to penetrate the skin so that it can reduce the pain. The other substance usually found in the rubbing oil is the anti-inflammatory substance extracted from garlic which has a powerful effect in reducing inflammation and swelling. The other traditional ingredient used here is pepper because it is believed to have a substance that can relieve joint pain and it is very important to cure a broken arm. Clove is also important as an element in the oil for massaging and rubbing because of its aromatic therapy power. Besides, this speciality balm has been widely used for a long time all over West Java as a substance employed to obtain optimal results in soothing muscles aches and pains. That is why clove oil is very ideal for reducing pains suffered by the patient of a broken-arm. The other popular ingredient in traditional medicine is lemon-grass, a kind of tropical grass with a lemon-like flavour usually used in Indonesian cooking. The substance extracted from lemon-grass is considered effective for achy joints and stomachache. Sometimes people also add cinnamon extract into the massaging or rubbing oil because it is regarded as having anti-inflammatory properties so that it can help the body fight infections and repair tissue damage. That's why it is significant in repairing a broken-arm patient. The other plant that can be grown easily but has power in 
lightening inflammation and swelling is an onion. It is often used to strengthen the effectiveness of massaging the oil in treating the patient (Ferguson, 2002; Packer, Choon, \& Halliwell, 2004; Weil, 2005; Arora, 2010; Suryani et al., 2018).

As has been previously mentioned, the above traditional attempts in curing the patient, the healer also made use of mantra. The mantra is being uttered repeatedly all along the time or during the masseur rubs and presses the patient's broken arm with regular movements, in order to relax it or to reduce stiffness or pain in his muscles, joints or broken bones. There are complementary efforts to cure the broken arm, namely the herbal or oil containing certain substances that are believed having the power to penetrate the skin, vein, tissue so that it can reach the broken bone, and the massage that may put the broken bone into the right position. Besides, the power of the mantra or prayer that the masseur repeatedly utters as the reflection of his strong belief in Allah, the Almighty God. Without the help of Allah, the masseur can do nothing as mentioned in the last line Pet rapet ku kersaning Allah 'the broken bone is cured or closely united because of the help from Allah'.

There are some other medicinal mantras which are named in accord with the purpose of the mantra itself like the one below.

\section{Data 3}

Mantra and its translation

Jampe Nyeri Beuteung (Mantra for Stomachache)

Bismillah (in the name of Allah, the Almighty God)

Peujit pabeulit (the intestines are intertwined)

Puseur pacangreud (the navel is twisted)

Ka luhur pindah ka jantung (the pain moves upwards to the heart)

Salatri pindah ka cai (the ache of hunger moves to the water/ stream)

Belekbek belegu (the sound of the stomach)

Belekbek belegu (the sound of the stomach)

The medicinal mantra above is in the form of a poetic mantra, there is a repetition of the sound /p/ and also /eu/ in peujit, pabeulit, puseur, pacangreud like in a verse of a poem, and the sound is believed to have an effect to soothe the pain. In other words, the repetition of a consonant and a vowel in those Sundanese words is intended to give suggestion to the hearer or the patient in order to support the healing efforts.

There are concords between peujit pabeulit and puseur pacangreud. Some words chosen are those which have an association with stomach as beuteung, peujit, puseur. Besides, in the Sundanese language pabeulit 'intertwined' indicates something in a disordered complex condition that is needed to be put in order. Onomatopoeia is also used to give an emphasis on the effort to cure the stomachache. This mantra is repeatedly spoken while the traditional medical practitioner is giving herbal medicine to the patient.

From the point of view of mimetic function, the mantra reflects its role in traditional therapeutic efforts existing among the community that shows the facets of their culture that is still inseparable with the life of their ancestors. It illustrates the way they live like their belief in the invisible power that gives hand to help cure the patient. It is a kind of contradictory with modern scientific therapeutics where everything is conducted on the bases of scientific theory and experiments. 
Viewed from its expressive function, the medicinal mantra above indicates the interaction and interpersonal communication among members of the community, and at the same time reflecting the relation with nature like the one expressed by the word cai 'water or stream' which has hidden meaning to throw away the illness to the stream. The expression salatri pindah $k a$ cai is used to influence the patient's thought in order to have an effect on him so that he believes that his illness has been gone. Explicitly, the words are not a part of the conversation between the traditional healer and the patient, they are in one line of the verse of mantra. However, it implicitly indicates interpersonal relations as a part of speech communication in the process of the treatment.

We are of the opinion that the most important function of mantra is the pragmatic function because it is closely related to speech communication including interpersonal relations among the members of the community and also between the community and the people outside. As a kind of poetic literature, mantra only has its meaning when it lives within the community and can also be enjoyed or has a benefit for other people outside the community, for instance in the field of educational, cultural and unique wellness tourism activities.

The other benefit for understanding Sundanese mantra is that it can help foster maintaining language and culture because to understand an old poetic literary work the reader has to know the language, the culture and the way of life of the community. To understand an expression like salatri pindah ka cai the reader has to know the language, the culture and how the people lived in the past. A long time ago, when someone suffered a stomachache or diarrhoea they went to a small river nearby because they did not have a toilet like we do today. The repeated sounds belekbek belegu belekbek belegu as onomatopoeia that similar to the sound of disordered digestion or the sound of water in a stream or small river.

For readers in general, reading a mantra is like reading a poetic literary work as a poem, but it has its own uniqueness because it takes the reader to the past with old culture and way of life. Besides, for a practitioner like a traditional healer, each mantra has its own goal. He reads mantra with a certain intention and he has a strong belief that the mantra has the power to help fulfil his need.

\section{CONCLUSION}

The results of the research indicate that the mimetic and expressive functions of mantra reflect the role of traditional therapeutic efforts as well as interpersonal relations among the members of the community. The extralinguistic elements are employed to arouse suggestion in order to support the effort of a treatment. In a modern world like today, communication is crucial for the development of health care in all areas, including at the villages where the Baduy people live, as shown by the discussion in this paper. The traditional therapeutic efforts in the research are in the form of a combination between traditional herbal medicines and the Baduy mantra. The opening and closing remarks of the mantra indicates that the community have a strong belief in the Almighty God. The body of the mantra is arranged in such a way which shows that the diction, repetitions and other linguistic elements play a significant role. The extralinguistic elements are employed to arouse suggestion in order to support the effort of a treatment. 


\section{ACKNOWLEDGEMENT}

Acknowledgement is extended to Kemenristekdikti Indonesia (Ministry of Research, Technology and Higher Education of the Republic of Indonesia) providing a grant for the research through PDUPT research program of 2017-2018.

\section{BIODATA}

Heriyanto is an associate professor at Universitas Padjadjaran, Indonesia. Email: heriyanto@unpad.ac.id

Ekaning Krisnawati is an assistant professor at Universitas Padjadjaran, Indonesia. Email: ekaning@unpad.ac.id

Elis Suryani is is an associate professor at Universitas Padjadjaran, Indonesia. Email: elis.suryani@unpad.ac.id

Eva Tuckyta Sari Sujatna is is a professor at Universitas Padjadjaran, Indonesia. Email: eva.tuckyta@unpad.ac.id

Kasno Pamungkas is a is an assistant professor at Universitas Padjadjaran, Indonesia. Email: kasno.pamungkas@unpad.ac.id 


\section{REFERENCES}

Arora, R. (2010). Medicinal plant biotechnology. Wallingford: CABI.

Basit, A. (2017). Health communication in the Quran: Charles Saunders Pierce's semiotic analysis. Jurnal Komunikasi: Malaysian Journal of Communication, 33(4), 76-88.

Ekadjati, E. S. (2014). Kebudayaan Sunda: Suatu pendekatan sejarah. Bandung: Pustaka Jaya.

Briggs, J. (2005). The use of indigenous knowledge in development: Problems and challenges. Progress in Development Studies, 5(2), 99-114.

Ferguson, W. J., \& Candib, L. M. (2002). Family medicine and community health "Culture, language and doctor-patient relationship". Retrieved from https://escholarship.umassmed.edu/finch_articles/61

Harrison, L., \& Huntington, S.P. (2000). Culture matters: How values shape human progress. New York: Basic Books.

Iskandar, J., \& Budiawati. (2017). Local knowledge of the Baduy community of South Banten (Indonesia) on the traditional landscapes. Biodiversitas, 18(3), 928-938.

Lingpa, J., Rinpoche, P., \& Mahapandita, G. (2006). Diety mantra and wisdom. New York: Snow Lion Publications.

Napoli, M. (2008). The plants, rituals and spells that 'cured' helminthiasis in Sicily. Journal of Ethnobiology and Ethnomedicine, 4(21). https://www.doi.org/10.1186/1746-4269-421.

Packer, L., Choon, N. O., \& Halliwell, B. (2004). Herbal and traditional medicine. NY: Marcel Dekker.

Paltridge, B. (2000). Making sense of discourse analysis. Brisbane: Gold Coast.

Riley, P. (2008). Language, culture and identity: An ethnolinguistics perspective. London: Continuum.

Saini, K. M. (2001). Pendidikan Pasundan masa depan [Future Pasundan education]. Bandung, Indonesia: Semiloka Transformasi Nilai budaya Sunda.

Semali, L, \& Kincheloe, J. L. (1999). What is indigenous knowledge?. New York: Falmer Press.

Sucipto, T., \& Limbeng, J. (2007). Studi tentang religi masyarakat Baduy di Desa Kanekes provinsi Banten [A study on religious Baduy people at Kanekes Village Banten province]. Jakarta: Departemen Kebudayaan dan Pariwisata.

Sumardjo, J. (2010). Sunda: Pola rasionalitas budaya [Cultural rationality pattern]. Bandung: Kelir.

Suryadi, E., \& Kusnendi. (2010). Kearifan lokal dan perilaku edukatif, ilmiah dan religius [Local wisdom and educative, scientific, and religious behaviors]. Paper presented at the 4th International Conference on Teacher Education (pp. 601-618). Retrieved from file.upi.edu $>$ Direktori $>$ FPEB $>132296305-$ RASTO

Suryani, E. (2017a). Mantra dan pengobatan [Mantra and medication]. Bandung: Pasulukan Loka Gandasasmita.

Suryani, E. (2017b). Baduy: Masa kini antara konvensi dan Inovasi [Baduy: Now between convention and innovation]. Bandung: Pasulukan Loka Gandasasmita.

Suryani, E., Heriyanto, \& Husen, I.R. (2018). Tanaman obat tradisional berbasis naskah dan kearifan lokal masyarakat Baduy [Manuscript-based traditional medicical plants and local wisdom of Baduy people] . Bandung: PT Raness Media Rancage.

Vaishnav, H. (2016). Tools and techniques for effective communication skills. Linguistic and Literature Studies, 4(1), 23-26.

Weil, A. (2005). Consumer guide to herbal medicines. Watertown: Body and Soul Omnimedia. 
Speech Communication Related to the Process of Traditional Therapeutic Efforts among the Baduy People in Lebak Regency, Indonesia

Heriyanto, Ekaning Krisnawati, Elis Suryani N. S., Eva Tuckyta Sari Sujatna \& Kasno Pamungkas

World Health Organization (WHO). Legal status of traditional medicines and complementary/ alternative medicine: A worldwide review. Retrieved from http://apps.who.int/medicinedocs/en/d/Jh29432e/ 